\title{
Impact of chia (Salvia hispanica L.) on the immune system: preliminary study
}

\author{
I. Fernandez ${ }^{1}$, S. M. Vidueiros ${ }^{1}$, R. Ayerza ${ }^{2}$, W. Coates $^{2}$ and A. Pallaro ${ }^{1}$ \\ ${ }^{1}$ Department of Nutrition, School of Pharmacy and Biochemistry, University of Buenos Aires, Argentina and \\ ${ }^{2}$ Office of Arid Lands Studies, University of Arizona, Tucson, Arizona 85706, USA
}

Chia was one of the four basic foods of Central American civilizations in pre-Columbian times. Nowadays, this crop is being reintroduced to Western diets to improve human health because it is an important source of $n$ - 3 fatty acids, antioxidants, dietary fibre, protein, vitamins and minerals, and when added to animal diets it elicits a reduction in the SFA contents of the animal products and serum lipids ${ }^{(1,2)}$. The protein quality of chia has been demonstrated to be higher than that of common cereals, which could be important in thymus development since previous studies have shown that protein quality affects thymus status ${ }^{(3,4)}$. However, adverse reaction to food is frequently observed among populations, and its symptoms may be localized in many organs and systems ${ }^{(5)}$. The aim of the present study was to analyse the effect of chia on some aspects of immune system such as the thymus and serum IgE concentration. Weanling male Wistar rats ( $23 \mathrm{~d}$ of age) from the Department of Nutrition at the School of Pharmacy and Biochemistry of the University of Buenos Aires, were divided in three groups (six rats each) that received for 1 month (g/kg diet): 150 ground chia seed (T1); 50 chia oil (T2); no chia (T3; control group). Diets T1 and T2 were formulated to provide equal quantities of $\alpha$-linolenic acid from the chia. All the experimental diets were isoenergetic, contained $(\mathrm{g} / \mathrm{kg}) 200$ protein and 70 oil, and were prepared according to the American Institute of Nutrition guidelines ${ }^{(6)}$. Food intake was recorded (FI; g/d). At the end of the experimental period and after $4 \mathrm{~h}$ of fasting body weight (BW; g) was recorded. Animals were anaesthetized in a $\mathrm{CO}_{2}$ chamber and blood was recollected by venous puncture and used to determined serum $\mathrm{IgE}$ levels (ng/ml) by ELISA (Bethyl Labs, Montgomery, TX, USA). Thymuses were removed, weighed $\left(\mathrm{TW} ; \mathrm{mg} / \mathrm{P}^{0.75}\right.$ ) and total thymocyte number (TN; no. of cells per organ) was determined using a Newbauer chamber. Statistical analysis was performed using ANOVA $t$ test.

\begin{tabular}{|c|c|c|c|c|c|c|}
\hline \multirow[b]{2}{*}{ Diet group ... } & \multicolumn{2}{|c|}{$\mathrm{T} 1$} & \multicolumn{2}{|c|}{$\mathrm{T} 2$} & \multicolumn{2}{|c|}{$\mathrm{T} 3$} \\
\hline & Mean & SD & Mean & $\mathrm{SD}$ & Mean & $\mathrm{SD}$ \\
\hline FI $(g / d)$ & 16.03 & 0.99 & 14.64 & 1.24 & 15.46 & 0.95 \\
\hline BW (g) & 265.78 & 24.01 & 238.88 & 40.25 & 259.26 & 27.50 \\
\hline $\mathrm{TW}\left(\mathrm{mg} / \mathrm{P}^{0.75}\right)$ & 12.16 & 1.53 & 11.12 & 1.16 & 11.07 & 2.42 \\
\hline $\mathrm{TN}$ (cells $\times 10^{-7} /$ organ) & 109.5 & 17.68 & 81.19 & 18.90 & 98.83 & 15.21 \\
\hline $\operatorname{IgE}(\mathrm{ng} / \mathrm{ml})$ & 6.77 & 4.06 & 4.67 & 1.05 & 3.18 & 1.05 \\
\hline
\end{tabular}

No significant differences were observed in FI, BW, TW, TN and IgE levels when chia was added to experimental diets as seeds (T1) or as oil (T2) when compared with the control (T3). Moreover, no symptoms such as dermatitis, diarrhoea and abnormal animal growth and behaviour were observed. Adding chia seeds or oil to experimental diets did not produce any of the problems associated with other $n-3$ fatty acid sources such as flaxseed or marine products, e.g. fishy flavour, weight loss, digestive problems, diarrhoea and allergies, as has been proposed $^{(1)}$.

1. Ayerza R \& Coates W (2005) Nutr Res 25, 995-1003.

2. Fernandez I, Ayerza R, Coates W, Vidueiros SM, Slobodianik NH \& Pallaro AN (2005) Medicina (Bs As) 65, Suppl. II, Abstr $259: 113.3$.

3. Pallaro A, Feliu MS., Vidueiros S, Slobodianik N, Ayerza R, Coates W \& Fernandez I (2004) Congreso Internacional de Ciencia y Tecnología de los Alimentos. Argentina. http://www.eatchia.com/pallarosp.htm

4. Pallaro A, Roux ME \& Slobodianik NH (2001) Nutrition 17, 724-728.

5. Foschi FG, Marsigli L, Chiappelli F, Kung MA, Bernardi M \& Stefanini GF (2000) Adverse reactions to foods. In Nutrition and Immunology, pp. 233-246 [ME Gershwin, JB German and CL Keen, editors]. Totowa, NJ: Humana Press.

6. American Institute of Nutrition (1993) J Nutr 123, 1939-1951. 